\title{
Transparency, Social Responsibility and Corporate Governance: Human Capital of companies
}

\section{Transparencia, Responsabilidad Social y Gobierno Corporativo: el Capital Humano de las empresas}

\author{
Francisca Tejedo-Romero ${ }^{1}$ \\ Joaquim Filipe Ferraz Esteves Araujo ${ }^{2}$ \\ University of Castilla-La Mancha (Spain) \\ University of Minho (Portugal)
}

Recibido el 21 de septiembre de 2016, aceptado el 12 de septiembre de 2017

Publicado online el 20 de febrero de 2018

$\mathrm{N}^{\mathrm{o}}$ de clasificación JEL: M19, M49

DOI: $10.5295 / \mathrm{cdg} .160693 \mathrm{ft}$

\begin{abstract}
:
Companies develop their activity in an environment characterized by knowledge-based economies, with qualified and highly skilled workers. Human Capital is one of the most important intangible resources that companies have to generate sustainable wealth. The main objective of this paper is to analyse the Human Capital information provided by companies in the field of Corporate Social Responsibility and Corporate Governance. Using the methodology of content analysis, this paper analyses the Human Capital disclosure contained in social responsibility reports of Spanish companies belonging to the IBEX 35. In addition, it identifies factors related to Corporate Governance (characteristics of the Board of Directors, and ownership structure of companies) with greatest impact on information provision. Balanced panel data are used to test our hypotheses. Empirical evidence shows a quadratic $U$-shaped relationship among the size of the board, independence, and the ownership concentration with Human Capital disclosure; and an inverted U-shaped relationship between managers' ownership of shares and Human Capital disclosure. In addition, it has been found that companies with greater gender diversity on their Board, as well as with greater board activity, tend to disclose more information related to Human Capital.
\end{abstract}

Keywords:

Transparency, Human Capital, Social Responsibility, Corporate Governance.

\section{Resumen:}

Las empresas desarrollan su actividad en un entorno caracterizado por economías basadas en el conocimiento, con mano de obra competente y altamente cualificada. El Capital Humano es uno de los recursos de naturaleza intangible más importantes que poseen las empresas para generar riqueza de manera sostenible. El principal objetivo de este trabajo es analizar la información del Capital Humano suministrada por las empresas

1 Faculty of Economic and Business Sciences of Albacete. Department of Business Administration. Plaza de la Universidad, 1, 02071, Albacete (Spain).Francisca.Tejedo@uclm.es

2 School of Economics and Management. Department of International Relations and Public Administration. Campus de Gualtar. 4715-343, Braga (Portugal).jfilipe@eeg.uminho.pt 
dentro del ámbito de la Responsabilidad Social Empresarial y del Gobierno Corporativo. Mediante la metodología del análisis de contenido, se analiza la información relativa al Capital Humano contenida en las memorias de responsabilidad social de las empresas españolas pertenecientes al IBEX 35. Además, se determinan aquellos factores relativos al Gobierno Corporativo (características del Consejo de Administración y estructura de la propiedad de la empresa) que mayor incidencia tienen en el suministro de información. Se emplea un panel de datos balanceado para testar nuestras hipótesis. La evidencia empírica obtenida muestra una relación cuadrática en forma de " $U$ " entre el tamaño del consejo, la independencia y la concentración accionarial con la revelación de Capital Humano; y una relación en forma de " $U$ " invertida entre el control accionarial de gestores y la información de Capital Humano. Además, se ha encontrado que aquellas empresas con mayor diversidad de género entre sus consejeros, así como con una mayor actividad del consejo, tienden a revelar más información relativa al Capital Humano.

\section{Palabras clave:}

Transparencia, Capital Humano, Responsabilidad Social, Gobierno Corporativo. 


\section{INTRODUCTION}

Social Responsibility and Corporate Governance, together with sustainable development in business performance, are issues that in recent years have aroused great interest both within companies and in general society (Muttakin and Khan 2014; Garrido-Miralles et al. 2016). In addition, recent financial and accounting frauds by some companies that have grabbed headlines have led some companies to improve their transparency, and to regain the lost trust in the markets and in society as a whole. All this is influencing the communication process of companies, and, as a result, the voluntary disclosure of information has become very important for more complete and transparent information disclosure by companies.

Under this scenario, it is particularly interesting to analyse the actions performed by companies, within the framework of Social Responsibility, namely those that generate value of an intangible nature. Specifically, Human Capital (hereinafter HC) is one of the most important intangible assets that companies have to sustainably generate wealth (Pedrini 2007; Tejedo-Romero and Araujo 2016). In this regard, analysing the voluntary disclosure of information as a practice of socially responsible behaviour by companies has been the latest interest of researchers. Studies show that socially responsible companies are those that provide the greatest amount of quality information. Thus, transparency is considered a key element of a good corporate governance system, and, therefore, business information disclosure is considered an integral part of Corporate Governance (OECD 2004; Rivero Torre 2005). It is in this context that this study aims to contribute toward deepening the existing knowledge on companies' voluntary disclosure of information, namely regarding HC, through Spanish companies' social responsibility reports.

The purpose of this paper is to develop and implement a framework that analyses the policy of voluntary disclosure of corporate information by companies related to HC, in the ambit of Corporate Social Responsibility and Corporate Governance. The idea is to find out what reasons lead companies to disclose more information, as a mechanism of greater transparency and socially responsible behaviour. The analysis is conducted through the content analysis of the information related to $\mathrm{HC}$ contained in social responsibility reports corresponding to companies belonging to IBEX35. The purpose of this is to identify which factors related to Corporate Governance have greater incidence on information disclosure. The methodology of content analysis and the subsequent statistical processing will follow a Tobit regression model for panel data. The results show a quadratic U-shaped relationship among the size of the board, independence, and the ownership concentration with HC disclosure; and an inverted-U relationship between the managers' ownership of shares and HC disclosure. In addition, it has been found that companies with greater gender diversity on their Board and with greater board activity tend to disclose more information related to HC.

The remainder of the article is organized as follows: the following section dwells on the theoretical framework and the research hypotheses that have been proposed. In the third section, the research methodology is explained. In the fourth section, the description and analysis of data are provided, as well as a discussion of the main findings. Finally, the main conclusions are presented in the fifth section. 


\section{THEORETICAL FRAMEWORK AND DEVELOPMENT OF HYPOTHESES}

\subsection{Human Capital: the main intangible asset of companies in the knowledge society}

$\mathrm{HC}$ is the main asset of companies (Sveiby 1997; Edvinsson and Malone 1999; Bontis 2001). It is the thinking asset that resides within company members (Roos et al. 2001). It represents the knowledge, skills, and abilities (Edvinsson and Malone 1999; Spangenberg 2016) that are incorporated into the individual or group of individuals during their lifetime, and used for the production of goods and services, representing a company's stock of individual knowledge (Bontis 2001).

Companies seek to retain their most valid employees (Roos et al. 2001; Pedrini 2007), rewarding those who possess such knowledge, as they are very useful to companies (Sveiby 1997; Spangenberg 2016). However, the growing concern in business management for socially responsible behaviour, in line with ethics and respect for labour rights, has led companies to look for, capture, retain, and manage talent and diversity of the people that make up the company, driving the generation of knowledge (HC). This business behaviour generates value, a value of an intangible nature that offers companies the ability to create, share, and manage the type of knowledge that underpins the generation of sustainable competitive advantages (Gelb and Strawser 2001; Tejedo-Romero 2014a; Spangenberg 2016).

Despite the relevance of this intangible asset, the strict requirements of accounting rules regarding its identification, measurement, and valuation (IASB 2004; PGC 2007) is such that it is not reflected in the financial statements of companies (Lev 2003; Abeysekera 2007; Pedrini 2007; Tejedo-Romero and Araujo 2016). On many occasions, the market value of companies does not coincide with the book value shown in their accounting books. This situation leads to a lack of usefulness of the information provided and, subsequently, to dissatisfaction with the information needs of the company's interest groups for decision-making. That is why companies are interested in offering users information that goes beyond what is established under commercial legislation (Tejedo-Romero 2014a), i.e., voluntary information.

\subsection{Information Transparency of Human Capital}

HC reporting and accountability by companies provides greater legitimacy to the activities carried out, attracts partners/investors, enhances reputation and prestige and, therefore, increases stakeholder trust in the company (Spangenberg 2016; Tejedo-Romero and Araujo 2016). $\mathrm{HC}$ information has been studied from two perspectives (knowledge/intellectual capital management, and social responsibility/sustainability), although authors such as Pedrini (2007) and Tejedo-Romero and Araujo (2016) find converging points between both perspectives.

The knowledge management/intellectual capital approach studies information on aspects such as education, vocational training, experience, skills and competencies in the workplace, the values and attitudes of workers, among others (White et al. 2007; Li et al. 2008; Nurunnabi et al. 2011; Joshi et al. 2012; De Silva et al. 2014). There are several conceptual frameworks that can be used to define, classify, and record HC information (Brooking 1997; Kaplan and Norton 1997; Sveiby 1997; Edvinsson and Malone 1999; 
Cañibano et al. 2002). The vast majority of empirical research has been based on Sveiby's (1997) initial framework. This has subsequently been modified in several studies (Guthrie and Petty 2000; Brennan 2001; Bozzolan et al. 2003; April et al. 2003; Goh and Lim 2004; Abeysekera and Guthrie 2005; Petty and Cuganesan 2005; Vandemaele et al. 2005; Nurunnabi et al. 2011; Joshi et al. 2012; De Silva et al. 2014; Spangenberg 2016).

The social responsibility/sustainability approach focuses on studying social and ethical information concerning relationships between workers and the company, health and safety in the workplace, diversity and equal opportunities, etc. (Rashid and Lodh 2008; Krüger 2009; Muttakin and Khan 2014; Martínez-Ferrero et al. 2015; Garrido-Miralles et al. 2016). There are guidelines and guides related to HC information (GRI 2000, 2002, 2006, 2011, 2013; CE 2001; AECA 2004, 2012). In recent years, there has been a great push by agencies and organizations for preparing sustainability or social responsibility reports. These reports are intended to provide information on business practices from economic, environmental and social perspectives (Pedrini 2007; Tejedo-Romero 2014a), and are useful documents for communicating with stakeholders (Pedrini 2007; Arvidsson 2010; Rodríguez-Gutiérrez et al.2013). In this regard, Spain is one of the leading countries in the preparation and dissemination of social responsibility reports by companies (Garrido-Miralles et al. 2016) with a clearly growing trend (García-Sánchez et al. 2011).

Thus, following Pedrini (2007) and Tejedo-Romero and Araujo (2016), this work has led to a consideration of a broader approach integrating both perspectives. This is due to the existence of connections between both, since the actions carried out by companies within the framework of social responsibility generate value, namely value of an intangible nature (Castilla and Gallardo 2008; Surroca et al. 2010; Veltri and Nardo 2013). It enables companies to create, share, and manage the type of knowledge that underpins the generation of sustainable competitive advantages (Tejedo-Romero 2014a).

Therefore, information related to $\mathrm{HC}$ is considered to mandatorily comprise both the aspects related to knowledge and social aspects related to socially responsible behaviour by companies (Pedrini 2007; Spangenberg 2016; Tejedo-Romero and Araujo 2016). In this regard, Spangenberg (2016) has prepared an HC development index to be used as a management tool that can help create socially responsible companies that foster human development.

On the other hand, the reasons why companies disclose voluntary information can be explained based on several theories: a) from the point of view of the Resources and $\mathrm{Ca}$ pabilities Theory (Hall 1992), the success and survival of companies depends, to a large extent, on the resources and capabilities that the company possesses. Companies report on a voluntary basis for the purpose of receiving investor support in the capital market (Abeysekera 2007; Sonnier 2008; Oliveira et al. 2010; Surroca et al. 2010); b) based on the postulates of the Legitimacy Theory, companies are interested in disclosing HC information for the purpose of legitimizing their situation and actions with employees before society in general (Oliveira et al. 2010; Nurunnabi et al. 2011; Castilla-Polo 2012; Rodríguez-Gutiérrez et al. 2013); and c) under the framework of the Stakeholders Theory, the success and survival of companies are considered to be subject to the approval of its stakeholders. Companies will disclose HC information in order to increase the company's perceived value (Bozzolan et al. 2003; Abeysekera and Guthrie 2005; Pedrini 2007; Oliveira et al. 2010; Spangenberg 2016). 


\subsection{Corporate Governance: a determining factor of information transparency on Human Capital}

Corporate Governance, whose key element is transparency, refers to a set of devices, mechanisms and structures that determine how companies are guided, managed and controlled, and whose existence leads to achieving the highest standards of management responsibility, accountability to shareholders, and creation of wealth (Babío-Arcay and Muíño-Vázquez 2003; García-Sánchez et al. 2011). It is a means of avoiding conflicts of interest and imbalances between majority and minority shareholders, and between shareholders and managers.

Several Codes of Corporate Governance Best Practices have been drafted, containing a set of recommendations and rules geared to company managers, so that they voluntarily put them into practice (Olivencia Report 1998; Aldama Report 2003; CUBGC 2006, 2013 , 2015). The idea is for Boards of Directors to fulfil their role as an internal supervision and control mechanism (AECA 2007), gaining trust through a strategy of social responsibility based on information transparency.

Thus, certain characteristics of the Board of Directors favour the articulation of rules and behaviours that can contribute towards improving supervision and control. This is a way of increasing transparency of information and the trust of future investors, minimizing possible conflicts of interests between insiders (agents) and outsiders (principal). It is derived from agency problems that arise due to the separation between the property and management of the company (García-Sánchez et al. 2011). Since the Board of Directors manages the disclosure of information, its characteristics may be relevant to influence the company's information disclosure policy (Li et al. 2008). Taking the Agency Theory as the theoretical basis, this study considers the following characteristics of the Board of Directors:

\section{A. Size of the Board}

The size of the Board is a feature related to the Board's efficiency for performing appropriate supervision and advisory tasks (García-Ramos and García 2011). Size can influence the company's level of disclosure of voluntary information. Babío and Muíño (2003), Cerbioni and Parbonetti (2007), Lim et al. (2007) and García-Sánchez et al. (2011), among others, consider that a larger number of directors has a negative impact on the Board's effectiveness, as the Board's supervising work might be hampered by lack of coordination and control. This implies extending the decision-making and communication process (Jensen 1993), affecting the company's information disclosure policy. On the other hand, a greater number of directors leads to an improvement of the board's advisory function, by bringing together the directors' collective knowledge and experience and, therefore, the need for HC information disclosure will be greater (Abeysekera 2010; Hidalgo et al. 2011; Allegrini and Greco 2013).

The Código Unificado de Buen Gobierno [Unified Code of Corporate Governance] (2006, p. 15) advises that the size of the Board should not be less than five or more than fifteen members. In this regard, several studies have found a quadratic relationship between the size of the Board and disclosure of information (Cerbioni and Parbonetti 2007; Prado-Lorenzo and García-Sánchez 2010; Hidalgo et al. 2011; Cuadrado, García and Martínez 
2015; Rodrigues, et al. 2017). Thus, it is proposed that the size of the board is not linearly associated with the disclosure of information, and a U-shaped relationship between both variables is expected to be found. This leads to the proposing of the first hypothesis:

H1: The size of the Board is negatively associated with the disclosure of $\mathrm{HC}$ information until an optimal size is obtained, after which the disclosure of HC information increases.

\section{B. Level of Board Activity}

A greater number of Board meetings is usually considered to be a measure of efficiency in developing the Board's supervisory and control function (Lipton and Lorsch 1992; Xie et al. 2003; Kanagaretnam et al. 2007). For directors, it implies a greater amount of time devoted to consultation, development of strategies, and controlling management (Prado et al. 2009; García-Sánchez et al. 2011; Allegrini and Greco 2013), resulting in less information asymmetry issues. Thus, the second hypothesis to be tested is as follows:

H2: A higher level of activity by the Board of Directors has a positive effect in terms of $\mathrm{HC}$ information disclosure.

\section{Duality}

When the position of Chairman of the Board and Chief Executive Officer falls on the same person, it may lead to ineffective and opportunistic behaviour (Jensen and Meckling 1976), due to excessive concentration of power. Still, this should theoretically favour the disclosure of information by reducing coordination costs (Jensen 1993; Coles et al. 2008). In fact, García-Sánchez et al. (2011) found a positive relationship with the disclosure of strategic information through the Internet.

However, the duality in the position can limit the Board's independence, and jeopardize the control and supervisory functions that, in turn, affect the company's information disclosure policy (Barako et al. 2006; Cerbioni and Parbonetti 2007; Li et al. 2008). The third hypothesis to be corroborated is:

H3: The dual role of Chief Executive Officer and Chairman of the Board is negatively related with the disclosure of $\mathrm{HC}$ information.

\section{Independence of the Board of Directors}

The strength of the Board of Directors is related to its members' degree of independence (Kang et al. 2007; Martínez-Ferrero et al. 2015), which is associated with the existence of independent directors. Directors must perform their duties without being conditioned by relationships with the company, and are appointed in accordance with their personal and professional qualifications (CUBGC 2006). Therefore, independence is closely linked to its members' knowledge and skills to control and supervise managers (De Andrés and Vallelado 2008; García-Sánchez et al. 2011).

Thus, the existence of independent directors may favour decision-making aimed at disclosing voluntary information (Chen and Jaggi 2000; Ho and Wong 2001; Babío and Muíño 2005; Barako et al. 2006; Cerbioni and Parbonetti 2007; Lim et al. 2007; Li et al. 2008; Gisbert and Navallas 2009; Prado et al. 2009; Martínez-Ferrero et al. 2015), 
reducing information asymmetries between managers and shareholders (Lim et al. 2007). However, empirical evidence does not provide conclusive results. There are works that find a negative impact between the Board's independence and voluntary disclosure of information (Eng and Mak 2003; Gul and Leung 2004; Barako et al. 2006; Rodrigues et al. 2017). Other studies find no relationship at all (Ho and Wong 2001; Haniffa and Cooke 2002; Ghazali and Weetman 2006; Hidalgo et al. 2011). A greater presence of independent members may be the reason why minority shareholders and other stakeholders demand less information, as a result of greater reliance placed on independent members (Rodrigues et al. 2017). In this regard, Cuadrado et al. (2015) find a quadratic relationship between the number of independent directors and corporate social responsibility practices. Therefore, following the previous approaches, the following hypothesis are proposed:

H4: The number of independent directors is negatively associated with disclosure of $\mathrm{HC}$ information until an optimal size is obtained, after which the disclosure of HC information increases.

\section{E. Gender Diversity on the Board}

The Unified Code of Corporate Governance (CUBG 2006) recommends the inclusion of women on the Board of Directors as a challenge, not only to the ethics, policies and Corporate Social Responsibility, but also to make it more efficient.

The presence of women in management positively influences the company's socially responsible behaviour (Martínez-Ferrero et al. 2015). The quick socialization that women experience, the role they play as a women and mothers (Prado et al. 2009), their more philanthropic and altruistic approach (Krüger 2009) and their leadership responsibilities tend to make them more participatory, democratic, and communitarian than men (Eagly and Johnson 1990). In addition, they have better knowledge of the market and are more prone to identifying with employees (Lucas-Pérez et al. 2015). In view of the above, this work intends to test the following hypothesis:

H5: Gender diversity on the Board of Directors has a positive impact as far as disclosure of $\mathrm{HC}$ information is concerned.

\section{F. Ownership Structure}

In addition, and within the framework of the Agency Theory, the company's ownership structure also plays a key role as a monitoring and control mechanism, when it comes to aligning shareholder interests with those of management (Jensen and Meckling 1976; Eng and Mak 2003). Shareholding control by managers (directors and executive members) and by major shareholders is considered a control mechanism within the ownership structure. Therefore, it can influence the level of voluntary disclosure of information (Eng and Mak 2003).

The agency problem caused by diverging interests between managers and shareholders can give rise to information asymmetries (Jensen and Meckling 1976). Thus, ownership of shares held by managers can help align interests between managers and shareholders (Eng and Mak 2003; Hidalgo et al. 2011). Low shareholding participation may result in managers having more incentives to behaving opportunistically, causing other stakeholders to increase monitoring over managerial behaviour (Jensen and Meckling 1976). One way 
to mitigate such a situation is by increasing the level of voluntary information, proving that they are acting in accordance with the interests of all owners and that their actions are transparent. The works of Eng and Mak (2003), Ahmed (2013), and Tauringana and Chithambo (2015) find that ownership of the directors' shares was negatively associated with the disclosure of information. On the other hand, Chau and Gray (2002) find a positive relationship between property in the hands of management and voluntary disclosure of information, since they, like other shareholders, are interested in creating long-term value in the company, and provide relevant information voluntarily (García-Sánchez et al. 2011). Thus, it is proposed that shareholding control by managers is not linearly associated with the disclosure of $\mathrm{HC}$ information, and an inverted U-shaped relationship between both variables is expected to be found. The following hypothesis will, therefore, be:

H6: Shareholding control by managers is positively associated with the disclosure of $\mathrm{HC}$ information until an optimum percentage of shares is reached, after which information will decrease.

On the other hand, agency costs are greater in companies where there is a great dispersion of the shareholder base, caused by asymmetries of information between managers and shareholders, and between minority shareholders and majority shareholders (Jensen 1993). One way to mitigate agency costs is by disclosing additional information. Jensen and Meckling (1976) suggest that a dispersed ownership structure would be expected to carry with it an incentive to provide more voluntary information to shareholders. However, previous research results on the relationship between concentration of ownership and voluntary disclosure of information are quite heterogeneous. While Chau and Gray (2002), Hannifa and Cooke (2002), and Tauringana and Chithambo (2015), find a positive relationship, others support a negative relationship (Barako et al. 2006; Li et al. 2008), or even no association at all (Eng and Mak 2003; Lim et al. 2007). Empirical evidence in this regard is not conclusive, either, and thus the following nonlinear relationship is proposed:

H7: Ownership concentration is negatively associated with the disclosure of HC information until an optimal percentage of shares in the hands of major shareholders is obtained, after which the disclosure of $\mathrm{HC}$ information increases.

\section{RESEARCH METHODOLOGY}

\subsection{Population and Sample}

The initial population comprises the companies listed on the Spanish stock market included in the IBEX 35 . This choice is motivated by being the most representative companies in Spain (Sierra-Garcia et al. 2013), as they have a greater number of stakeholders interested in them (De los Ríos et al. 2009). These are companies more transparent (Briano and Rodríguez 2013) for being the companies with the largest volume of stock capitalization in Spain. In addition, Law 26/2003 of $17^{\text {th }}$ July on information transparency require listed companies to have a website to disclose information and to publish their annual report, which facilitates access to the documents to be analysed. 
For the selection of the sample, a directed or non-probabilistic sampling was chosen. Thus, the companies included in the IBEX 35 are chosen as of December 31, 2014 and remain fixed for 8 years until $2007^{3}$. The final sample is made up of 23 companies $^{4}$, representing $65.7 \%$ of the initial population. Therefore, a balanced data panel with 184 observations (company-year) of 23 companies for 8 years has been used. The panel data methodology combines cross-sectional $(\mathrm{N}=23)$ and temporal $(\mathrm{T}=8)$ data, allowing a greater number of observations $(200=\mathrm{NxT})$ and degrees of freedom. It is a balanced micro panel (the same companies are analysed for the different years), where the cross-sectional dimension predominates over the temporal one. This methodology minimizes potential endogeneity issues (Cheung et al. 2010, p. 277), and improves the efficiency of econometric estimations, by capturing unobservable heterogeneity: a) of the specific individual effects of each company; and b) of the temporary effects (Wooldridge 2010; Baltagi 2014).

Table 1 shows the distribution of the sample by sector.

Table 1

Percentage of Participation by Sector

\begin{tabular}{lcccc}
\hline \multirow{2}{*}{ Sector } & \multicolumn{2}{c}{ Initial Population } & \multicolumn{2}{c}{ Final Sample } \\
\cline { 2 - 5 } & Companies & Percentage & Companies & Percentage \\
\hline Consumer Goods & 2 & $5,71 \%$ & 1 & $4,35 \%$ \\
Basic Materials / Industry and & 10 & $28.57 \%$ & 6 & $26,09 \%$ \\
Construction & 6 & $17.14 \%$ & 5 & $21.74 \%$ \\
Oil \& Energy & 4 & $11.43 \%$ & 2 & $8,70 \%$ \\
Consumer Services & 9 & $25.71 \%$ & 7 & $30.43 \%$ \\
Financial and Real Estate Services & 4 & $11.43 \%$ & 2 & $8,70 \%$ \\
Technology and Telecommunica- & 35 & $100 \%$ & 23 & $100 \%$ \\
tions & & & & \\
TOTAL & &
\end{tabular}

Source: Own elaboration.

The table shows that all sectors of the initial population are characterized.

3 The time period has been limited to 2007 because there are not many companies that have a large time horizon regarding publication of their social responsibility reports on the Web. The normal history timeframe is about 5 to 10 years. Law 26/2003 only requires companies to have a website, and to publish their report or annual report. Social responsibility reports are voluntary and, in recent years, the tendency has been to integrate them into the annual reports (integrated report). These reports were obtained directly from company websites and were compiled in early 2016; on that date, the latest published reports were for the financial year 2014.

4 A total of 27 companies are listed on IBEX 35 throughout the years under study. However, for 4 of these companies, it was impossible to obtain the social responsibility reports for the 8 years under study. Finally, information is available for a total of 23 companies from 2007 to 2014 . 


\subsection{Variables and Data Collection}

The following variables were selected to corroborate the hypotheses stated in the theoretical framework.

\section{A. Dependent Variable}

The dependent variable is the amount of HC information. In order to quantify this variable, disclosure indices have been prepared (Abeysekera and Guthrie 2005; Vuontisjärvi 2006) using the content analysis methodology (Beattie and Thomson 2007; Pedrini 2007; Tejedo-Romero 2014b). It is a data collection technique that attempts to encode qualitative and quantitative information into predefined categories, in order to obtain patterns of information presentation (Krippendorff 2004; Guthrie and Abeysekera 2006; Pedrini 2007).

Previous studies and guidelines discussed in Section 2 served as the basis for classifying and coding HC information into categories and elements. The framework was configured under 5 categories and 24 intangible elements (see Table 2).

The following analysis units have been considered: a) sampling units, which comprised social responsibility reports; $b$ ) context units, which allowed the analysis of information at sentence level; and c) registration units, which consisted of the presence or absence of information. Thus, the items were obtained from 184 social responsibility reports that were analysed.

The quantification system to prepare the $\mathrm{HC}$ disclosure index has been made by using the following counting rule: 1 if the company has disclosed a certain intangible element (item), and 0 otherwise. In addition, disclosure sub-indices have been developed corresponding to the five HC subcategories. Thus, unweighted disclosure indices have been developed by aggregating the score obtained for each item (Beretta and Bozzolan 2008). This approach is consistent with that used in other studies (Giner 1997; Oliveira et al. 2010). Weighted indices by the degree of subjectivity connected to the weights used have not been used, since there is no universally accepted weighting table (Giner 1995). Instead, a different score is assigned to each item, depending on the relevance established by the researcher himself. Finally, an adjustment is made, by dividing by the maximum number of intangible elements that could be disclosed within each of the HC subcategories. This adjustment, as stated by Marston and Shrives (1991), and by Botosan (1997), is made so as not to penalize those companies that, for whatever reason, cannot disclose some of the items or entries considered (see Table 3). 
Table 2

Framework Used for Encoding HC Information

\section{EMPLOYEES (11 items):}

1. Employee Profile

2. Equal opportunities and diversity issues

3. Employee Health and Safety

4. Labour Relations and Trade Union Activity

5. Worker Involvement with the Community

6. Employee Recognition

7. Outstanding Employees

8. Employee Commitment

9. Employee Motivation

10. Employee Behaviour

11. Economic Data

\section{EDUCATION (2 items):}

12. Regulated Education

13. Professional Qualifications

\section{TRAINING AND DEVELOPMENT (6 items):}

14. Employee Education and Training Policy

15. Efforts in Employee Education and Training

16. Skills Development Policy

17. Career Opportunities

18. Internal Promotion

19. Hiring/Recruitment Policy

\section{WORK-RELATED KNOWLEDGE (3 items):}

20. Know-How

21. Quality and Professional Experience

22. Performance and Results of Senior Managers

\section{ENTREPRENEURIAL SPIRIT (2 items):}

23. Innovative Employee Ideas

24. Employee Consultation and Suggestion System

Source: Own elaboration. 
Table 3

HC Disclosure Sub-Indices and Index

\begin{tabular}{l}
\hline Subindex Employees $j_{j}=\frac{1}{11} \sum_{i=1}^{11} X_{i j}$ \\
\hline Subindex Education $n_{j}=\frac{1}{2} \sum_{i=1}^{2} X_{i j}$ \\
\hline Subindex Training and Development $t_{j}=\frac{1}{6} \sum_{i=1}^{6} X_{i j}$ \\
Subindex Wark related Knowledge $e_{j}=\frac{1}{3} \sum_{i=1}^{3} X_{i j}$ \\
\hline Subindex Entrepreneurial Spirit $t_{j}=\frac{1}{2} \sum_{i=1}^{2} X_{i j}$ \\
Index Human Capital $l_{j}=\frac{1}{24} \sum_{i=1}^{24} X_{i j}$ \\
\hline
\end{tabular}

Source: Own elaboration.

Where: HC Index is the unweighted disclosure index of company $j, i$ is the element; $X_{i j}$ is the score obtained for element $i$ by company $\mathrm{j}$. Consequently, $X i j$ will take up the value 1 if company $j$ has disclosed element $i$; otherwise, it will take up the value 0 if it has not been disclosed. In addition, 24 is the total number of items that comprise the HC information table.

Data coding has been performed manually with the support of the qualitative data analysis program MAXQDA. An initial coding was performed for a pilot sample of 5 social responsibility reports, obtaining a value for Krippendorff alpha of 0.80 , which suggests an acceptable level of agreement between coders (Krippendorff 2004; Beattie and Thomson 2007). The content analysis was performed on all the analysed reports.

\section{B. Independent Variables}

The data for the independent variables were obtained from the annual corporate governance reports.

Size of the Board: represents the total number of members of the Board of Directors (Rodrigues et al. 2017). In addition, the square of this variable has also been included, to help determine a possible U-shaped relationship between the size of the Board and the disclosure of HC.

Board Activity: represents the number of meetings held by the members of the Board of Directors (Prado-Lorenzo and García-Sanchez 2010). It is measured as the number of meetings held by the Board of Directors during the financial year.

Duality: represents duality in the position of Chief Executive Officer and Chairman of the Board of Directors. It is a dummy variable that takes the value 1 when both functions fall on the same person, and zero when the functions are separated (Barako et al. 2006; Cerbioni and Parbonetti 2007; Li et al. 2008). 
Independence: represents the percentage of independent external directors sitting on the Board of Directors (Barako et al. 2006; Cerbioni and Parbonetti 2007; Li et al. 2008). It is measured as the ratio of the total number of independent directors to the total number of Board members. The square of this variable has also been included to help determine the possible existence of a quadratic relation.

Gender Diversity: represents the percentage of women sitting on the Board of Directors. This variable is measured as the ratio of the total number of female directors to the total number of Board members (Barako and Brown 2008; Prado-Lorenzo and GarcíaSanchez 2010).

Shareholding Control by Managers: represents the percentage of shares held by directors and executive members. The square of this variable has also been included to help determine the possible existence of a quadratic relation.

Ownership Concentration: A numerical variable representing the proportion of ordinary shares owned by substantial shareholders (with equity of 5 per cent or more) (Rodrigues et al. 2017). The square of this variable has also been included to help determine a possible U-shaped relationship between ownership concentration and the disclosure of HC.

\section{Control Variables}

The following control variables have been considered:

Sensitive Sectors: these are sectors more likely to have socially responsible information policies (Simnett et al. 2009; Kolk and Perego 2010), disseminating a greater amount of voluntary information. It is a dummy variable that takes the value 1 when the company belongs to a sensitive section, and 0 otherwise. Thus, consistent with Sierra-Garcia et al. (2014), the following are considered to be sensitive sectors: financial and real estate services; technology and telecommunications; and oil and energy. In addition, it is expected that companies more likely to engage in socially responsible behaviour may moderate the role of gender diversity within the Board over voluntary disclosure of $\mathrm{HC}$ information. In this respect, the interaction of this variable with the sector has been included in order to determine the possible moderating effect.

Company Age: Some authors have considered that the age of the company can be a constraint for providing voluntary information (Bukh et al. 2005; Cerbioni and Parbonetti 2007; White et al. 2007; Rashid and Lodh 2008). Mature companies are concerned with their reputation and will disclose more information voluntary (Muttakin and Khan 2014). This variable, which represents the company's years of existence in the market, is measured as the number of years from the incorporation date.

Company Size: Big companies are those that tend to have a greater number of interested parties in the voluntary information they disclose, since they are the ones that are more exposed to public opinion. Size was measured based on the number of employees (Bozzolan et al. 2003; Bukh et al. 2005; Rodrigues et al. 2017).

Profitability: Profitability can be the result of continuous investment in HC, and, therefore, companies can take part in greater disclosure of such information to indicate the importance they have in creating long-term value. The ROA has been used as a measure of economic profitability (Giner 1997; Sierra-Garcia et al. 2013).

Year: Dummies have been considered for each of the years under study. 


\subsection{Research Model}

An econometric panel data model has been used with a total of 184 observations $(\mathrm{N}=$ $23 \times \mathrm{T}=8$ ). This methodology minimizes possible problems with endogeneity of variables (Cheung et al. 2010). In addition, it improves the efficiency of econometric estimates by capturing unobservable heterogeneity: a) of the specific individual effects of each company, and b) of the temporary effects (Hsiao 2003; Wooldridge 2010; Baltagi 2014).

The econometric model is as follows:

$$
H C_{i t}=\alpha+\beta_{1} \text { Board Size }_{i t}+\beta_{2} \text { Board Size }_{i t}^{2}+\beta_{3} \text { Board Activity }_{i t}+\beta_{4} \text { Duality }_{i t}+\beta_{5}
$$
Independence $_{i t}+\beta_{6}$ Independence $_{i t}{ }^{2}+\beta_{7}$ Gender Diversity $_{i t}+\beta_{8}$ Managers Control $_{i t}+\beta_{9}$ Managers Control $_{i t}{ }^{2}+\beta_{10}$ Ownership Concentration $_{i t}+\beta_{11}$ Ownership Concentration $_{i t}{ }^{2}+$ $\beta_{12}$ Sensitive Sector ${ }_{i t}+\beta_{13}$ Gender Diversity $_{i t} x$ Sensitive Sector ${ }_{i t}+\beta_{14}$ Company Age $_{i t}+\beta_{15}$ Size $_{i t+} \beta_{16}$ Profitability $_{i t}+\beta_{17}$ Year $_{i t}+v_{i t}$

$$
v_{i t}=\mu_{i}+\varepsilon_{i t}
$$

Where:

$i$ represents the company $(i=1, \ldots . ., 23)$ and $t$ relates to the time period $(t=2007, \ldots . ., 2014)$. $\alpha$ is the constant, $\beta$ are the parameters to be estimated. $v_{\mathrm{it}}$ is the random error term, which is broken down into 2 elements: $\mu_{\mathrm{i}}$, which is the individual effect that characterizes each company and is invariant over time; and $\varepsilon_{\text {it }}$, which varies according to companies and over time.

The HC disclosure index takes values between 0 and 1 . The estimation using a Tobit model is adequate because it allows considering a dependent variable with limits on the right and left, as is the case. The Tobit model provides coefficients using the maximum likelihood method. It uses the random effects estimator to control the individual heterogeneity of companies, taking into account that companies are observed in different periods of time. Two estimates will be made: a Tobit pool model; and a Tobit for panel data. In addition, the Likelihood-ratio test will be applied, which compares the pool estimator against a panel Tobit to see which model is the best.

The econometric software Stata 12.1 has been used.

\section{RESEARCH RESULTS AND DISCUSSION}

\subsection{Descriptive Analysis}

Table 4 shows the results of the descriptive statistics for $\mathrm{HC}$ information and its different categories.

IBEX 35 companies provide information on their $\mathrm{HC}$, with values higher than 0.5 . These values do not vary much over the years under study. During the period of crisis, companies appear to have maintained their levels of information, with a slight increase in 2014, the year in which they began to recover from the crisis period (Ahmed 2013; Rodrigues et al. 2017). This may be due to the fact that, in times of crisis, companies have a more cost-effective information disclosure policy (the costs of producing and disseminating in- 
formation may outweigh the benefits). In fact, in the work of Garrido-Miralles et al. (2016), the authors conclude that, in a context of economic crisis, social responsibility reports lose power and, therefore, the disclosure of information is not so relevant.

However, based on the framework of the Theories of Resources and Capabilities, Legitimacy and Stakeholders, it can be stated that companies are voluntarily providing information on their $\mathrm{HC}$ in social responsibility reports. The most widely disseminated information pertains to employee Training and Development. Thus, companies supply this type of information as a way to legitimize responsible behaviour towards stakeholders on their knowledge-generating strategy. On the other hand, they may consider that their HC is the most valuable resource and do not want their employees to leave the company, and therefore, information associated with work-related knowledge is the least disseminated.

Table 4

Descriptive Statistics of HC Information (Index and Sub-Indices)

\begin{tabular}{lccccccccc}
\hline & $\mathbf{2 0 0 7}$ & $\mathbf{2 0 0 8}$ & $\mathbf{2 0 0 9}$ & $\mathbf{2 0 1 0}$ & $\mathbf{2 0 1 1}$ & $\mathbf{2 0 1 2}$ & $\mathbf{2 0 1 3}$ & $\mathbf{2 0 1 4}$ & $\mathbf{2 0 0 7 -}$ \\
\hline HC & & & & & & & & & $\mathbf{2 0 1 4}$ \\
Average & 0.623 & 0.639 & 0.625 & 0.634 & 0.643 & 0.661 & 0.681 & 0.701 & 0.651 \\
Max & 0.875 & 0.833 & 0.833 & 0.833 & 0.833 & 0.833 & 0.833 & 0.875 & 0.875 \\
Min & 0.25 & 0.458 & 0.208 & 0.333 & 0.458 & 0.458 & 0.5 & 0.5 & 0.208 \\
\hline Employees & & & & & & & & & \\
Average & 0.668 & 0.692 & 0.676 & 0.7 & 0.711 & 0.723 & 0.743 & 0.763 & 0.71 \\
Max & 1 & 1 & 1 & 0.909 & 0.909 & 0.909 & 0.909 & 1 & 1 \\
Min & 0.182 & 0.454 & 0.273 & 0.545 & 0.454 & 0.454 & 0.454 & 0.454 & 0.182 \\
\hline Education & & & & & & & & & \\
Average & 0.674 & 0.63 & 0.63 & 0.63 & 0.652 & 0.674 & 0.652 & 0.652 & 0.649 \\
Max & 1 & 1 & 1 & 1 & 1 & 1 & 1 & 1 & 1 \\
Min & 0 & 0.5 & 0.5 & 0 & 0.5 & 0.5 & 0.5 & 0.5 & 0 \\
\hline Training and & & & & & & & & & \\
Development & & & & & & & & & \\
Average & 0.783 & 0.804 & 0.775 & 0.804 & 0.797 & 0.826 & 0.841 & 0.855 & 0.811 \\
Max & 1 & 1 & 1 & 1 & 1 & 1 & 1 & 1 & 1 \\
Min & 0.5 & 0.667 & 0.167 & 0.167 & 0.333 & 0.333 & 0.333 & 0.333 & 0.167 \\
\hline Work-Related & & & & & & & & & \\
Knowledge & & & & & & & & & \\
Average & 0.304 & 0.319 & 0.319 & 0.275 & 0.261 & 0.261 & 0.261 & 0.304 & 0.288 \\
Max & 0.667 & 0.667 & 0.667 & 0.667 & 0.667 & 0.667 & 0.667 & 0.667 & 0.667 \\
Min & 0 & 0 & 0 & 0 & 0 & 0 & 0 & 0 & 0 \\
\hline Entrepreneurial Spirit & & & & & & & & & \\
Average & 0.326 & 0.348 & 0.348 & 0.304 & 0.37 & 0.413 & 0.522 & 0.543 & 0.397 \\
Max & 1 & 1 & 1 & 1 & 1 & 1 & 1 & 1 & 1 \\
Min & 0 & 0 & 0 & 0 & 0 & 0 & 0 & 0 & 0 \\
\hline N (Observations) & $\mathbf{2 3}$ & $\mathbf{2 3}$ & $\mathbf{2 3}$ & $\mathbf{2 3}$ & $\mathbf{2 3}$ & $\mathbf{2 3}$ & $\mathbf{2 3}$ & $\mathbf{2 3}$ & $\mathbf{1 8 4}$ \\
\hline Sarce Ony & & & & & & & & & \\
\hline
\end{tabular}

Source: Own elaboration using STATA statistics. 
Along the same line, and for all years, the descriptive statistics for the independent and control variables are shown in Table 5.

The Size of the Board has shown similar values over the years, with an average number of directors of 15 members throughout the period, with a maximum of 24 members and a minimum of 8 . However, a size between 5 and 15 members is advised (CUBG 2006).

As for the Board's Activity, companies have held the same number of meetings over time, with an average of 11 meetings per year. In this regard, the Boards of Directors have met almost once a month. While the Unified Code of Corporate Governance (2006) does not establish a limit, it recommends that meetings be held at a certain frequency to effectively fulfil the functions of the Board of Directors.

As far as separation of the functions of CEO and Chairman of the Board is concerned, over the period, the positions are in the hands of different people in $17 \%$ of the cases, whereas there is duality in the position in $83 \%$ of the sample companies. This situation may jeopardize the control and supervisory functions of the Board of Directors (Li et al. 2008), and affects the policy of voluntary disclosure.

There was a moderate increase in the percentage of Independent Directors on the Boards of Directors. This increase may be motivated by the recommendation of the Unified Code of Corporate Governance (2006) to increase the percentage of independent directors, so that Boards of Directors are more independent and neutral.

It is worth mentioning the increase of Female Directors on the Boards of Directors. CUBGC (2006) recommended the inclusion of women on the Board of Directors as a challenge, not only in terms of ethics, policies, and Corporate Social Responsibility, but also as an efficiency goal for that body. This increase may also be associated with the approval, in 2007, of the Gender Equality Law in Spain. However, we find companies that, during the 8 years, have not included any women on their Boards (minimum equal to zero).

The percentage of Shares Held by Managers is not too high, at only $14 \%$ over the period. Although there are companies where the maximum percentage of shares in their possession is $80 \%$, in others, they have no ownership of company shares. On the other hand, the Ownership Concentration by the main shareholders amounts to an average of $29 \%$ over the eight years.

The average Company Age is 63 years, although there is a large dispersion compared to the average (42.7 years), as there are 158-years-old companies, and young companies that are only 6 years old. In addition, $61 \%$ of companies belong to Sensitive Sectors, and 39\% do not. The average Size of Companies in the sample is 51,407 employees, and their average Profitability is 3.76. There has been a very rapid decline over the years, which may have been motivated by the effects of the economic crisis. 
Table 5

Descriptive Statistics of Independent and Control Variables

\begin{tabular}{lccccccccc}
\hline \multicolumn{7}{c}{ Panel A: Continuous Variables } \\
\hline & $\mathbf{2 0 0 7}$ & $\mathbf{2 0 0 8}$ & $\mathbf{2 0 0 9}$ & $\mathbf{2 0 1 0}$ & $\mathbf{2 0 1 1}$ & $\mathbf{2 0 1 2}$ & $\mathbf{2 0 1 3}$ & $\mathbf{2 0 1 4}$ & $\begin{array}{c}\mathbf{2 0 0 7} \text { - } \\
\text { (2014 }\end{array}$ \\
\hline $\begin{array}{l}\text { Size of the } \\
\text { Board } \\
\text { Average }\end{array}$ & 15 & 15.1 & 15.2 & 15.2 & 15.1 & 14.8 & 14.6 & 13.8 & 14.9 \\
Max & 22 & 24 & 24 & 23 & 22 & 21 & 20 & 18 & 24 \\
Min & 8 & 9 & 9 & 9 & 9 & 9 & 9 & 9 & 8 \\
\hline Board & & & & & & & & & \\
Activity & & & & & & & & & \\
Average & 11 & 10.5 & 10.8 & 10.8 & 11.3 & 11.1 & 11.2 & 11 & 11 \\
Max & 17 & 14 & 17 & 16 & 18 & 17 & 15 & 18 & 18 \\
Min & 5 & 5 & 6 & 5 & 5 & 5 & 5 & 5 & 5 \\
\hline Indepen- & & & & & & & & & \\
dence & & & & & & & & & \\
Average & 0.417 & 0.424 & 0.441 & 0.44 & 0.44 & 0.447 & 0.469 & 0.449 & 0.441 \\
Max & 0.786 & 0.786 & 0.8 & 0.786 & 0.786 & 0.786 & 0.714 & 0.786 & 0.8 \\
Min & 0.067 & 0.067 & 0.077 & 0.071 & 0.056 & 0.067 & 0.214 & 0.214 & 0.056 \\
\hline
\end{tabular}

Gender

Diversity

\begin{tabular}{lccccccccc} 
Average & 0.071 & 0.086 & 0.102 & 0.113 & 0.132 & 0.147 & 0.156 & 0.181 & 0.123 \\
Max & 0.238 & 0.273 & 0.3 & 0.273 & 0.308 & 0.364 & 0.364 & 0.5 & 0.5 \\
Min & 0 & 0 & 0 & 0 & 0 & 0 & 0 & 0 & 0 \\
\hline Manager & & & & & & & & & \\
Control & & & & & & & & & \\
Average & 0.151 & 0.162 & 0.15 & 0.149 & 0.162 & 0.13 & 0.117 & 0.102 & 0.14 \\
Max & 0.629 & 0.652 & 0.6 & 0.593 & 0.802 & 0.594 & 0.593 & 0.594 & 0.802 \\
Min & 0 & 0 & 0 & 0 & 0 & 0 & 0 & 0 & 0 \\
\hline
\end{tabular}

\section{Ownership}

Concentra-

tion

\begin{tabular}{lccccccccc} 
Average & 0.322 & 0.303 & 0.29 & 0.288 & 0.276 & 0.272 & 0.288 & 0.281 & 0.29 \\
Max & 0.786 & 0.789 & 0.792 & 0.794 & 0.796 & 0.747 & 0.686 & 0.684 & 0.796 \\
Min & 0 & 0 & 0 & 0 & 0 & 0 & 0 & 0 & 0 \\
\hline
\end{tabular}

\section{Company}

Age

\begin{tabular}{lccccccccc} 
Average & 59.7 & 60.7 & 61.7 & 62.7 & 63.7 & 64.7 & 65.7 & 66.7 & 63.2 \\
Max & 151 & 152 & 153 & 154 & 155 & 156 & 157 & 158 & 158 \\
Min & 5.83 & 6.83 & 7.83 & 8.83 & 9.83 & 10.8 & 11.8 & 12.8 & 5.83 \\
\hline Size & & & & & & & & & \\
Average & 45022 & 47975 & 52900 & 54410 & 55975 & 55215 & 49238 & 50518 & 51407
\end{tabular}




\begin{tabular}{lccccccccc} 
Max & 244052 & 251775 & 255151 & 269047 & 286144 & 272598 & 186540 & 217908 & 286144 \\
Min & 734 & 727 & 729 & 711 & 706 & 710 & 709 & 689 & 689 \\
\hline Profitability & & & & & & & & & \\
Average & 6.64 & 5.52 & 3.66 & 4.26 & 3.22 & 1.79 & 2.32 & 2.7 & 3.76 \\
Max & 45.3 & 25.1 & 20.8 & 23.6 & 23.4 & 24.3 & 22.2 & 21.1 & 45.3 \\
Min & -1.15 & -1.47 & -3.31 & .28 & -12.8 & -11.5 & -13 & -5.84 & -13 \\
\hline $\begin{array}{l}\text { N (Obser- } \\
\text { vations) }\end{array}$ & $\mathbf{2 3}$ & $\mathbf{2 3}$ & $\mathbf{2 3}$ & $\mathbf{2 3}$ & $\mathbf{2 3}$ & $\mathbf{2 3}$ & $\mathbf{2 3}$ & $\mathbf{2 3}$ & $\mathbf{1 8 4}$ \\
\hline
\end{tabular}

Panel B: Dummy Variables

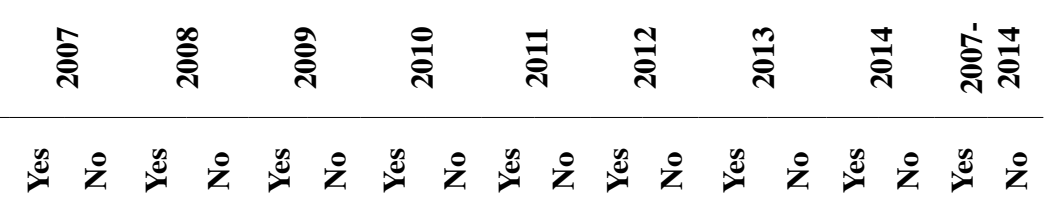

\section{Duality}

Percentage

$(\%)$

$\begin{array}{llllllllllllllllll}83 & 17 & 87 & 13 & 87 & 13 & 87 & 13 & 87 & 13 & 83 & 17 & 78 & 22 & 74 & 26 & 83 & 17\end{array}$

\section{Sensitive}

Sector

Percentage $(\%)$

\begin{tabular}{llllllllll}
\hline $\begin{array}{l}\text { N (Observa- } \\
\text { tions) }\end{array}$ & 23 & 23 & 23 & 23 & 23 & 23 & 23 & 23 & 184 \\
\hline
\end{tabular}

Source: Own elaboration using STATA statistics.

Some of the variables suffer from normality problems. For the following analyses, the natural logarithm of the variables Size of the Board, Board Activity, Age and Size of the Company has been taken. However, the use of a Tobit regression does not require fulfilling as many requirements and assumptions as in a linear regression.

\subsection{Multivariate Analysis}

The results of the Tobit regression model are in Table 6 below. Thus, the third and fourth columns detail the results of the Tobit Pool, and of the Tobit random model for panel data. The value of the Likelihood-ratio test ( $p$-value $=0.000)$ shows that, for the data set, it is preferable to estimate the model with a Tobit random model for panel data. 
Table 6

Outcome of the Panel Data Regression Model

\begin{tabular}{|c|c|c|c|}
\hline \multirow[b]{2}{*}{$\begin{array}{l}\text { Dependent and Control } \\
\text { Variables }\end{array}$} & \multicolumn{3}{|c|}{ Independent Variable: HC Information } \\
\hline & $\begin{array}{c}\text { Hypothesis / } \\
\text { Prediction Sign }\end{array}$ & $\begin{array}{l}\text { POOLED TOBIT } \\
\text { Coef } /(\text { Std. Error) }\end{array}$ & $\begin{array}{c}\text { RE TOBIT } \\
\text { Coef./(Std. Error) }\end{array}$ \\
\hline Size of the Board & $\mathrm{H} 1(-)$ & $\begin{array}{c}0.2244083 \\
(0.6501959)\end{array}$ & $\begin{array}{c}-1.536355^{* * *} \\
(0.5485061)\end{array}$ \\
\hline Size of the Board ${ }^{2}$ & $\mathrm{H} 1(+)$ & $\begin{array}{l}-0.0599124 \\
(0.1258628)\end{array}$ & $\begin{array}{c}0.2826549 * * * \\
(0.1060348)\end{array}$ \\
\hline Board Activity & $\mathrm{H} 2(+)$ & $\begin{array}{c}0.0636952 * * \\
(0.0309786)\end{array}$ & $\begin{array}{c}0.0693234 * * * \\
(0.0243591)\end{array}$ \\
\hline Duality & H3 (-) & $\begin{array}{c}-0.0489328 * * \\
(0.0219164)\end{array}$ & $\begin{array}{l}-0.0004379 \\
(0.0179558)\end{array}$ \\
\hline Independence & $\mathrm{H} 4(-)$ & $\begin{array}{c}0.2490807 \\
(0.2468167)\end{array}$ & $\begin{array}{l}-0.9832 * * * \\
(0.2358633)\end{array}$ \\
\hline Independence $^{2}$ & $\mathrm{H} 4(+)$ & $\begin{array}{l}-0.2659292 \\
(0.2514126)\end{array}$ & $\begin{array}{l}1.041613 * * * \\
(0.2432075)\end{array}$ \\
\hline Gender Diversity & $\mathrm{H} 5(+)$ & $\begin{array}{c}0.1549625 \\
(0.1174379)\end{array}$ & $\begin{array}{c}0.3517471 * * * \\
(0.0954839)\end{array}$ \\
\hline Manager Control & H6 (+) & $\begin{array}{c}0.6174917 * * * \\
(0.1341022)\end{array}$ & $\begin{array}{c}0.2426388 * * \\
(0.113377)\end{array}$ \\
\hline Manager Control ${ }^{2}$ & H6 (-) & $\begin{array}{c}-0.8465816^{* * *} \\
(0.223182)\end{array}$ & $\begin{array}{l}-0.50837 * * * \\
(0.1791965)\end{array}$ \\
\hline Ownership Concentration & H7 (-) & $\begin{array}{c}-0.3088549 * * \\
(0.1220603)\end{array}$ & $\begin{array}{c}-0.3756161 * * * \\
(0.0987721)\end{array}$ \\
\hline Ownership Concentration ${ }^{2}$ & $\mathrm{H} 7(+)$ & $\begin{array}{l}0.6114222 * * * \\
(0.163806)\end{array}$ & $\begin{array}{c}0.4074383 * * * \\
(0.1319086)\end{array}$ \\
\hline Sensitive Sector & & $\begin{array}{c}0.0695425 * * \\
(0.0272353)\end{array}$ & $\begin{array}{c}0.1256668 * * * \\
(0.0223513)\end{array}$ \\
\hline $\begin{array}{l}\text { Gender Diversity x Sensiti- } \\
\text { ve Sector }\end{array}$ & & $\begin{array}{l}0.0993743 \\
(0.160199)\end{array}$ & $\begin{array}{c}-0.5619568 * * * \\
(0.1423479)\end{array}$ \\
\hline Company Age & & $\begin{array}{c}0.0129418 \\
(0.0128211)\end{array}$ & $\begin{array}{l}-0.0038623 \\
(0.0103997)\end{array}$ \\
\hline Size & & $\begin{array}{c}0.003311 \\
(0.0058354)\end{array}$ & $\begin{array}{l}-0.0017159 \\
(0.0047452)\end{array}$ \\
\hline Profitability & & $\begin{array}{c}-0.0073266 * * * \\
(0.0013054)\end{array}$ & $\begin{array}{l}-0.0015623 \\
(0.0011694)\end{array}$ \\
\hline Year 2008 & & $\begin{array}{c}0.006519 \\
(0.0249868)\end{array}$ & $\begin{array}{c}0.0146853 \\
(0.0194302)\end{array}$ \\
\hline Year 2009 & & $\begin{array}{l}-0.0261133 \\
(0.0253933)\end{array}$ & $\begin{array}{l}-0.0032172 \\
(0.0198661)\end{array}$ \\
\hline
\end{tabular}




\begin{tabular}{|c|c|c|}
\hline Year 2010 & $\begin{array}{l}-0.0164425 \\
(0.0254334)\end{array}$ & $\begin{array}{c}0.0053328 \\
(0.0198882)\end{array}$ \\
\hline Year 2011 & $\begin{array}{c}-0.0147337 \\
(0.0258656)\end{array}$ & $\begin{array}{c}0.0097697 \\
(0.0202594)\end{array}$ \\
\hline Year 2012 & $\begin{array}{l}-0.0146496 \\
(0.0269273)\end{array}$ & $\begin{array}{c}0.0289792 \\
(0.0213825)\end{array}$ \\
\hline Year 2013 & $\begin{array}{c}0.0025972 \\
(0.0271528)\end{array}$ & $\begin{array}{c}0.0624942 * * * \\
(0.021928)\end{array}$ \\
\hline Year 2014 & $\begin{array}{c}0.0229485 \\
(0.0287172)\end{array}$ & $\begin{array}{c}0.0904592 * * * \\
(0.0233178)\end{array}$ \\
\hline (Constant) & $\begin{array}{c}0.1725452 \\
(0.8263577)\end{array}$ & $\begin{array}{c}2.730872 * * * \\
(0.711596)\end{array}$ \\
\hline sigma & $\begin{array}{c}0.084016 \\
(0.0044117)\end{array}$ & \\
\hline sigma_u & & $\begin{array}{c}0.0912029 * * * \\
(0.0089798)\end{array}$ \\
\hline sigma_e & & $\begin{array}{c}0.0652315 * * * \\
(0.0035133)\end{array}$ \\
\hline rho & & $\begin{array}{c}0.6615677 \\
(0.0515931) \\
\end{array}$ \\
\hline Observations & 184 & 184 \\
\hline Log-likelihood & 190.40491 & 204.31347 \\
\hline LR chi2(23)/Wald chi2(23) & $115.61 * * *$ & $177.33 * * *$ \\
\hline Likelihood-ratio test: $\chi^{2}$ (probability) & \multicolumn{2}{|c|}{$\operatorname{chibar}^{2}(01)=27.82 * * *$} \\
\hline
\end{tabular}

Tobit results for panel data show that the coefficients of the variables Size of the Board and Size of the Board ${ }^{2}$ are negative and positive, respectively, and significant at a $1 \%$ significance level. This shows the existence of a quadratic U-shaped relationship between the Size of the Board and HC information. These results are consistent with those obtained in previous studies (Cerbioni and Parbonetti 2007; Hidalgo et al. 2011; Prado-Lorenzo and García-Sánchez 2010; Rodrigues et al. 2017), confirming the first hypothesis (H1). Thus, there is an optimal level (which is of 15 board members for the whole of the sample), below which there is an improvement in the voluntary disclosure of $\mathrm{HC}$. This supports the argument of an adequate combination in the number of board members.

The second hypothesis (H2) regarding Activity of the Board of Directors is confirmed, for a $1 \%$ level of significance. A greater number of meetings reduces possible problems of information asymmetries, since with more frequent meetings the supervisory and control functions attributed to the Board are more efficient (Kanagaretnam et al. 2007; Prado et al. 2009). This result is similar to that obtained in the paper of Allegrini and Greco (2011). 
It has not been possible to corroborate the third hypothesis (H3) regarding companies where the functions of Chief Executive Officer and Chairman of the Board fall on the same person. In these companies, there is less disclosure of HC information.

The variables Independence and Independence ${ }^{2}$ show significant coefficients for a $1 \%$ level of significance and are negative and positive, respectively. It confirms the quadratic U-shaped relationship between Independence and HC information. This relationship is consistent with the results of research by Cuadrado et al. (2015), confirming the fourth hypothesis (H4). The optimum percentage of independent Directors on the Board stands at $47.2 \%$, where the reduction of independent members on the Board improves the voluntary disclosure of information.

Gender Diversity shows a positive relationship at $1 \%$ level of significance. Boards of Directors with more women provide more $\mathrm{HC}$ information. It confirms that women show a more responsible behaviour concerning information disclosure (Prado et al. 2009; Martínez-Ferrero et al. 2015). In this regard, the fifth hypothesis (H5) is accepted.

The coefficients of the variables Manager Control and Manager Control ${ }^{2}$ are positive and negative, respectively, and are significant. This shows the existence of an inverted U-shaped quadratic relationship between the percentage of shares held by managers and HC information. In this regard, García-Ramos and García (2011) also found a quadratic relation between shares held by managers and directors, and performance. Thus, the optimal percentage of shares held by managers and directors is $23.86 \%$, from which more shares held by them worsen or decreases the disclosure of $\mathrm{HC}$ information. Therefore, the sixth hypothesis (H6) is corroborated.

The variables Ownership Concentration and Ownership Concentration ${ }^{2}$ show significant coefficients for a $1 \%$ level of significance, and are negative and positive, respectively. It confirms the quadratic U-shaped relationship between Ownership Concentration and HC information. The seventh hypothesis (H7) is accepted. The optimum percentage of shares held by major shareholders is $46.1 \%$, where the reduction of shares held by major shareholders improves HC information.

Concerning control variables, it must be pointed out that: $a$ ) there is a positive relationship for a $1 \%$ significance level with sensitive sectors, with companies belonging to such sectors providing the most HC information. These are sectors that display a socially responsible behaviour regarding their information disclosure policy (Simnett et al. 2009; Kolk and Perego 2010). The Gender Diversity vs. Sensitive Sector term interaction has also been shown to be significant, confirming the impact of gender diversity on disclosure of information (effect: $\beta_{7}=0.3517471$ ). It is greater when firms belong to sensitive sectors, and lower when they belong to sectors not so committed to socially responsible behaviour (effect: $\beta_{7}$ Gender Diversity $+\beta_{13}$ Gender Diversity $x$ Sensitive Sector $=0.3517471$ $-0.5619568=-0.2102097) ; b$ ) the years 2013 and 2014 were significant, as it was in those years that more information was disclosed by companies in the sample; $c$ ) the company age, size and profitability variables were not significant. 


\section{CONCLUSIONS}

Society's demand for greater information transparency by companies is becoming a regular practice for its socially responsible behaviour. In particular, voluntary disclosure of information is becoming of great importance in the business world. Corporate Governance of companies must provide the necessary means to increase the degree of transparency and the quality of information disclosed, in order to reflect the true image of company's assets.

$\mathrm{HC}$ is the main intangible asset that companies have to generate value. However, the strict requirements of accounting regulations prevent these resources from being identified in companies' balance sheets. The first goal of this work has been to develop and apply an $\mathrm{HC}$ information framework, integrating the dimensions of Intellectual Capital and Social Responsibility. The purpose was to analyse HC information disclosure policies carried out by Spanish companies in their accountability reports. The second goal was to help determine the Corporate Governance mechanisms that can influence the amount of information disclosed.

This is a contribution to the study of voluntary information on $\mathrm{HC}$, from the perspective of knowledge generation and sustainability, through an 8-year longitudinal study (20072014). The analysis uses panel data in order to study the trend that companies are following in their policies on voluntary disclosure of information. Under the postulates of the theories of resources and capacity, legitimacy and stakeholders, results show that companies are providing voluntary information on HC. They are keeping up with their levels of information disclosed over the years. Although in the years under study the levels of information disclosure are quite similar, there is a slight increase in the amount of information provided in 2014. This may be due to the "economic crisis effect." In a time of crisis, companies have a more austere policy because the costs associated with preparing and providing information may outweigh the benefits achieved. Since economic recovery started to occur in 2014, companies have increased the amount of disclosed HC information. Information regarding employee training and development is the most disclosed category, while the least disclosed is the category related to knowledge of employees on their job.

However, the greater or lesser disclosure of HC information has been conditioned by a number of determinants. Results confirm that there is a quadratic U-shaped relationship between the disclosure of HC and the following variables: Size of the Board, Board Activity, Independence of the Board, and Ownership Concentration. That is to say, the greater the size, the greater the activity, the more independence, and the more ownership concentration, the less HC information is disclosed until an optimum level is reached, from which more $\mathrm{HC}$ information is disclosed. An inverted U-shaped quadratic relationship has also been found regarding the percentage of shares held by directors and executive members. The greater the percentage of shares, the greater the information disclosed, until an optimum is reached, percentage from which disclosure of information decreases.

On the other hand, more HC information is disclosed in companies with greater number of female directors, and in those that belong to sectors that are more sensitive to public opinion. Additionally, it has been found that more sensitive sectors have a moderating effect on the relationship between gender diversity in Boards of Directors and HC information. Finally, the years 2013 and 2014 have a positive and significant relationship with disclosed information. We have not found any significant relationship between the 
Remaining Years, Duality, Profitability, and Company Age and Size, and the disclosure of $\mathrm{HC}$ information.

Under the Agency Theory, this paper has attempted to provide evidence on the existence of certain Corporate Governance mechanisms, which can be used to reduce conflicts of interests arising from asymmetries of information between principal and agent, in order to increase information transparency and ethical behaviour on the part of companies. These results could be of interest to all other Spanish companies or from outside Spain, when adopting recommendations from Corporate Governance codes. It would allow them to know which Corporate Governance features have an influence on policies related to disclosure of HC information, as IBEX 35 companies are a good benchmark in the Spanish capital market. Likewise, it may be useful for accounting regulators when considering it in developing future recommendations and regulations regarding $\mathrm{HC}$ information. It is useful, as well, for regulators or issuers of Corporate Governance codes regarding future modifications of existing codes.

This study has some limitations that could be addressed in future research studies. Firstly, the size of the sample is limited; only the companies included in IBEX 35 have been studied. It would be interesting to expand this study further, with listed companies not included in IBEX 35, and even with non-listed companies. Secondly, the time period for data collection could be expanded, and even unbalanced panel data may be used, as there have been numerous changes in reports published by companies from the time they were implemented to the present. Thirdly, the geographical scope. Future research could be geared to other capital markets that may have cultural and legal similarities. Finally, the preparation of the disclosure index is not weighted; it would be interesting to use a weighted index based on the relevance of items or categories for the various stakeholders.

\section{ACKNOWLEDGEMENTS}

This study was conducted at the Research Centre in Political Science (UID/ CPO/00758/2013), University of Minho, and was funded by the Portuguese Foundation for Science and Technology, and by the Portuguese Ministry of Education and Science through national funds.

\section{REFERENCES}

Abeysekera, I., 2006. The project of intellectual capital disclosure: Researching the research. Journal of Intellectual Capital, 7(1), 61-75.

Abeysekera, I., 2007. Intellectual capital reporting between a developing and developed nation. Journal of Intellectual Capital, 8(2), 329-345.

Abeysekera, I and Guthrie, J., 2005. An empirical investigation of annual reporting trends of intellectual capital in Sri Lanka. Critical Perspectives on Accounting, 16 (3), 151-163.

Ahmed Haji, A. 2013. Corporate social responsibility disclosures over time: evidence from Malaysia. Managerial Auditing Journal, 28(7), 647-676. 
AECA, Asociación Española de Contabilidad y Administración de Empresas., 2004. Marco Conceptual de la Responsabilidad Social Corporativa. Documentos $\mathrm{n}^{\circ} 1$ de la Comisión de Responsabilidad Social Corporativa. AECA, Madrid.

AECA, Asociación Española de Contabilidad y Administración de Empresas., 2007. Gobierno y Responsabilidad Social de la Empresa. Documentos $n^{\circ} 4$ de la Comisión de Responsabilidad Social Corporativa. AECA, Madrid.

AECA, Asociación Española de Contabilidad y Administración de Empresas., 2012. Memoria AECA. AECA, Madrid.

Aldama Report., 2003. Report by the Special Commission to foster transparency and security in the markets and in listed companies. Council of Ministers, Madrid.

Allegrini, M. and Greco, G., 2013. Corporate boards, audit committees and voluntary disclosure: evidence from Italian listed companies. Journal of Management \& Governance 17, (1), 187-216.

Andres, P. and Vallelado, E., 2008. Corporate governance in banking: the role of the board of directors. Journal of Banking and Finance, 32(12), 2570-2580.

April, K.A., Bosma, P. and Deglon, D.A., 2003. IC measurement and reporting: Establishing a practice in SA mining. Journal of Intellectual Capital, 4(2), 165-180.

Arvidsson, S., 2010. Communication of corporate social responsibility: a study of the view of management teams in large companies. Journal of Business Ethics, 96(3), 339-354.

Babío, M. R. and Muíño, M. F., 2003. La influencia del sistema de gobierno de la empresa sobre la comunicación de información. Gestión científica empresarial: temas de investigación actuales. (pp. 349-363). La Coruña: Netbiblo, cop.

Babío, M.R. and Muíño, M. F., 2005. Corporate Characteristics, Governance Rules and the Extent of Voluntary Disclosure in Spain. Advances in Accounting, 21, 299-331.

Baltagi, B., 2014. Econometric Analysis of Panel Data. London, UK: Wiley.

Barako, D.G. and Brown, A.M., 2008. Corporate social reporting and board representation: evidence from the Kenyan banking sector. Journal of Management and Governance, 12 (4), 309-324.

Barako, D.G., Hancock, P. and Izan, H.Y., 2006. Relationship between corporate governance attributes and voluntary disclosures in annual reports: the Kenyan experience. Financial Reporting Regulation and Governance, 5 (1), 1-27.

Beattie, V. and Thomson, S.J., 2007. Lifting the lid on the use of content analysis to investigate intellectual capital disclosures. Accounting Forum, 31(2), 129-163.

Beretta, S. and Bozzolan, S., 2008. Quality versus quantity: the case of forward-looking disclosure. Journal of Accounting, Auditing \& Finance, 23(3), 333-376.

Bontis, N., 2001. Assessing knowledge assets: a review of the models used to measure intellectual capital. International Journal of Management Reviews, 3 (1), 41-60.

Botosan, C.A., 1997. Disclosure level and the cost of equity capital. Accounting Review, 72(3), 323-349.

Bozzolan, S., Favotto, F. and Ricceri, F., 2003. Italian annual intellectual capital disclosure: An empirical analysis. Journal of Intellectual Capital, 4(4), 543-558.

Brennan, N., 2001. Reporting intellectual capital in annual reports: Evidence from Ireland. Accounting, Auditing \& Accountability Journal, 14(4), 423-436.

Briano, G. and Rodríguez, L., 2013. Transparencia de la información corporativa en internet de las empresas del IBEX 35. Revista de Contabilidad y Dirección, 16, 187-208. 
Brooking, A., 1997. El capital intelectual: el principal activo de las empresas del tercer milenio [Intellectual capital: companies main asset in the third millennium]. Barcelona: Paidós Empresa.

Bukh, P., Nielsen, C., Gormsen, P. and Mouritsen, J., 2005. Disclosure of information on intellectual capital in Danish IPO prospectuses. Accounting, Auditing \& Accountability Journal, 18 (6), 713-32.

Cañibano, L., Sánchez, P., García-Ayuso, M. and Chaminade, C., 2002. Directrices para la Gestión y Difusión de Información sobre Intangibles (Informe sobre Capital Intelectual). MERITUM PROJECT. Madrid: Airtel Foundation.

Castilla, F. and Gallardo, D., 2008. La decisión de divulgar intangibles a través de una estrategia de triangulación teórica. Estudios de Economía Aplicada, 26(2), 79-104.

Castilla-Polo, F., 2012. Voluntary disclosures of intangible assets and legitimization: The production industry of olive oil. Intangible Capital, 8(3), 564-600.

EC, European Commission, 2001. Green Paper: Promoting a European Framework for Corporate Social Responsibility. Documents COM (2001) 366 final, Luxembourg, Publications Office of the European Union.

Cerbioni, F. and Parbonetti, A., 2007. Exploring the Effects of Corporate Governance on Intellectual Capital Disclosure: An Analysis of European Biotechnology Companies. European Accounting Review, 16(4), 791 - 826.

Chau, G. K. and Gray, S. J., 2002. Ownership structure and corporate voluntary disclosure in Hong Kong and Singapore. The International Journal of Accounting, 37, 247-265.

Chen C.J.P. and Jaggi, B., 2000. Association between independent non-executive directors, family control and financial disclosures in Hong Kong. Journal of Accounting and Public Policy, 19 (2), 285-310.

Cheung, Y.L., Jiang, P. and Tan, W., 2010. A transparency disclosure index measuring disclosures: Chinese listed companies. Journal of Accounting and Public Policy, 29 (3), 259-280.

Coles, J. L., Daniel, N. D. and Naveen, L., 2008. Boards: Does one size fit all?. Journal of Financial Economics, 87(2), 329-356.

Cuadrado, B., García, R. and Martínez, J., 2015. Efecto de la composición del consejo de administración en las prácticas de responsabilidad social corporativa. Revista de Contabilidad, 18(1), 20-31.

CUBGC, Código Unificado de Buen Gobierno., 2006. Informe del grupo especial de trabajo sobre buen gobierno de las sociedades cotizadas. Madrid: Ministerio de Economía y Hacienda.

CUBGC, Código Unificado de Buen Gobierno., 2013. Código Unificado de Buen Gobierno de las empresas cotizadas. Madrid: Ministerio de Economía y Hacienda.

CUBGC, Código Unificado de Buen Gobierno., 2015. Unified code of corporate governance. Informe del grupo especial de trabajo sobre buen gobierno de las sociedades cotizadas. Madrid: Ministerio de Economía y Hacienda.

De Andrés, P. and Vallelado, E., 2008. Corporate governance in banking: The role of the board of directors. Journal of Banking \& Finance, 32(12), 2570-2580.

De los Ríos, A., Torres, M., Tirado, P. and Carbonell, A., 2009. Stakeholders, intangibles y generación de valor en las empresas del IBEX-35: una estimación mediante modelos de panel. Revista Española de Financiación y Contabilidad, 38(142), 239-263. 
De Silva, T. A., Stratford, M. and Clark, M., 2014. Intellectual capital reporting: a longitudinal study of New Zealand companies. Journal of Intellectual Capital, 15(1), 157-172.

Eagly, A. H. and Johnson, B. T., 1990. Gender and leadership style: a meta-analysis. Psychological Bulletin, 108(2), 233-256.

Edvinsson, L. and Malone, M. S., 1999. El capital intelectual: Cómo identificar y calcular el valor de los recursos intangibles de su empresa. Barcelona, Gestión 2000.

Gan, K., Saleh, Z. and Abessi, M., 2008. Corporate Governance, Ownership Structures and Intellectual Capital Disclosures: Malaysian Evidence. 16th Conference on the Theories and Practices of Securities and Finance Markets. Department of Finance, National Sun Yat-Sen University. 5-6 December 2008, Kaohsiung, Taiwan.

García-Ramos, R. and García, M., 2011. Estructura del consejo de administración en la empresa familiar versus no familiar: evidencia empírica en España. Revista Española de Financiación y Contabilidad, 11(149), 35-64.

García-Sánchez I.M., Rodríguez-Dominguez L. and Gallego-Alvarez I., 2011. Corporate governance and strategic information on the internet. Accounting, Auditing and Accountability Journal, 24(4), 471-501.

Garrido-Miralles, P., Zorio-Grima, A. and García-Benau, M.A., 2016. Sustainable Development, Stakeholder Engagement and Analyst Forecasts' Accuracy: Positive Evidence from the Spanish Setting. Sustainable Development, 24(2), 77-88.

Gelb, D. S. and Strawser, J. A., 2001. Corporate Social Responsibility and Financial Disclosures: An Alternative Explanation for Increased Disclosure. Journal of Business Ethics, 33 (1), 1-13.

Giner, B., 1997. The influence of company characteristics and accounting regulation on information disclosed by Spanish firms. European Accounting Review, 6 (1), 45-68.

Gisbert, A. and Navallas, B., 2009. Gobierno corporativo e información voluntaria en las compañías cotizadas españolas, Estudios financieros. Revista de contabilidad y tributación: Comentarios, casos prácticos. Centro de Estudios Financieros, pp. 135-166.

Goh, P.C. and Lim, K.P., 2004. Disclosing intellectual capital in company annual reports:

Evidence from Malaysia. Journal of Intellectual Capital, 5(3), 500-510.

GRI, Global Reporting Initiative., 2000. Sustainability reporting guidelines G1.

GRI, Global Reporting Initiative., 2002. Sustainability reporting guidelines G2.

GRI, Global Reporting Initiative., 2006. Sustainability reporting guidelines G3.

GRI, Global Reporting Initiative., 2011. Sustainability reporting guidelines G3.1.

GRI, Global Reporting Initiative., 2013. G4 Sustainability Reporting Guidelines.

Guthrie, J. and Abeysekera, I., 2006. Content analysis of social, environmental reporting: what is new?, Journal of Human Resource Costing \& Accounting, 10(2), 114-126.

Guthrie, J. and Petty, R., 2000. Intellectual capital: Australian annual reporting practices. Journal of Intellectual Capital, 1(3), 241-251.

Guthrie, J., Petty, R. and Ricceri, F., 2006. The voluntary reporting of intellectual capital: Comparing evidence from Hong Kong and Australia. Journal of Intellectual Capital, $7(2), 254-271$.

Hall, R., 1992. The strategic analysis of intangible resources. Strategic Management Journal, 13(2), 135-144.

Ho, S.S.M. and Wong, K.S., 2001. A study of the relationship between corporate governance structures and the extent of voluntary disclosure. International Journal of Accounting, Auditing and Taxation, 10(2), 139-156. 
Hsiao, C., 2003. Analysis of Panel Data. New York, NY: Cambridge University Press.

IASB, International Accounting Standards Board, 2004. Intangible Assets International Accounting Standards, IAS 38. London: IASB.

Jensen, M.C., 1993. The modern industrial revolution, exit, and the failure of internal control systems. Journal of Finance, 48(3), 831-880.

Jensen, M.C. and Meckling, W.H., 1976. Theory of the firm: Managerial behavior, agency costs and ownership structure. Journal of Financial Economics, 3(4) 305-360.

Joshi, M., Ubha, D.S. and Sidhu, J., 2012. Intellectual capital disclosures by Indian and Australian information technology companies: A comparative analysis. Journal of Intellectual Capital, 13(4), 582-598.

Kanagaretnam, K., Lobo, G.J. and Whalen, D.J., 2007. Does good corporate governance reduce information asymmetry around quarterly earnings announcement. Journal of Accounting \& Public Policy, 26(4). 497-522.

Kang, H., Cheng, M. and Gray, S. J., 2007. Corporate governance and board composition: Diversity and independence of Australian boards. Corporate Governance: An International Review, 15(2), 194-207.

Kaplan, R.S. and Norton, D.P., 1997. Cuadro de mando integral. Gestión 2000, Barcelona.

Kolk, A. and Perego, P., 2010. Determinants of the adoption of sustainability assurance statements: an international investigation. Business Strategy and the Environment, 19 (3), 182-198

Krippendorff, K., 2004. Content analysis: An introduction to its methodology. California, Sage Publications, Inc.

Krüger, P., 2009. Corporate social responsibility and the board of directors. Job Market Paper. Toulouse School of Economics, France.

Lev, B., 2003. Intangibles: Medición, gestión e información. Ediciones Deusto [Publisher].

Li, J., Pike, R. and Haniffa, R., 2008. Intellectual capital disclosure and corporate governance structure in UK firms. Accounting and Business Research, 38(2) 137-159.

Lim, S., Matolcsy, Z. and Chow, D., 2007. The association between board composition and different types of voluntary disclosure. European Accounting Review, 16(3), 555-583.

Lipton, M. and Lorsh, J.W., 1992. A modest proposal for improved corporate governance. Business Lawyer, 48(1), 59-77.

Lucas-Pérez, M., Mínguez-Vera, A., Baixauli-Soler J., Martín-Ugedo, J. and SánchezMarín, G., 2015. Women on the board and managers' pay: Evidence from Spain. Journal of Business Ethics, 129, 265-280.

Marston, C. L. and Shrives, P. J., 1991. The use of disclosure indices in accounting research: a review article. The British Accounting Review, 23(3), 195-210.

Martínez-Ferrero, J., Vaquero-Cacho,L.A., Cuadrado-Ballesteros, B. and García-Sánchez, I. M., 2015. El gobierno corporativo y la responsabilidad social corporativa en el sector bancario: el papel del consejo de administración. European Research in Business Management and Economics, 21 (3), 129-138

Muttakin, M. B. and Khan, A., 2014. Determinants of corporate social disclosure: empirical evidence from Bangladesh. Advances in Accounting, 30(1), 168-175.

Nurunnabi, M., Hossain, M. and Hossain, M., 2011. Intellectual capital reporting in a South Asian country: evidence from Bangladesh. Journal of Human Resource Costing \& Accounting, 15(3), 196-233. 
OECD, 2004. OECD Principles of Corporate Governance. Paris: OECD Publications.

Oliveira, L., Rodrigues, L.L. and Craig, R., 2010. Intangible assets and value relevance: Evidence from the Portuguese stock exchange. British Accounting Review, 42(4), 241252.

Olivencia Report, 1998. Report of the Olivencia Committee on Corporate Governance. Council of Ministers, Madrid.

Pedrini, M., 2007. Human capital convergences in intellectual capital and sustainability reports. Journal of Intellectual Capital, 8(2), 346-366.

Petty, R. and Cuganesan, S., 2005. Voluntary disclosure of intellectual capital by Hong Kong companies: examining size, industry and growth effects over time. Australian Accounting Review, 15(36), 40-50.

PGC, Plan General De Contabilidad., 2007. Real Decreto 1514/2007, de 16 de noviembre, por el que se aprueba el Plan General de Contabilidad. Suplemento del BOE n ${ }^{\circ} 278,20$ de noviembre de 2007, Ministerio de Economía y Hacienda.

Prado, J. M., García, I. M. and Gallego, I., 2009. Características del consejo de administración e información en materia de Responsabilidad Social Corporativa. Revista Española de Financiación y Contabilidad, XXXVIII (141), 107-135.

Prado-Lorenzo, J. M. and Garcia-Sanchez, I. M., 2010. The role of the board of directors in disseminating relevant information on greenhouse gases. Journal of Business Ethics, 97(3), 391-424.

Prado-Lorenzo, J.M., Rodríguez-Domínguez, L., Gallego-Álvarez, I. and García-Sánchez, I.M., 2009. Factors influencing the disclosure of greenhouse gas emissions in companies world-wide. Management Decision, 47(7), 1133 - 1157.

Rashid, A. and Lodh, S. C., 2008. The influence of ownership structures and board practices on corporate social disclosures in Bangladesh. Research in Accounting in Emerging Economies, 8(1), 211-237.

Rivero Torre, P., 2005. Responsabilidad social y gobierno corporativo: información y transparencia. RAE: Revista Asturiana de Economía, (34), 9-29.

Rodríguez Gutiérrez, P., Fuentes García, F. J. and Sánchez Cañizares, S., 2013. Revelación de información sobre clientes, comunidad, empleados y medio ambiente en las entidades financieras españolas a través de las memorias de responsabilidad social corporativa (2007-2010). Investigaciones Europeas de Dirección y Economía de la Empresa, 19(3), 180-187.

Rodrigues, L., Tejedo-Romero, F. and Craig, R., 2017. Corporate governance and intellectual capital reporting in a period of financial crisis: Evidence from Portugal. International. Journal of Disclosure and Governance, 14(1), 1-29.

Roos, J., Dragonetti, N. C., Roos, G. and Edvinsson, L., 2001. Capital intelectual: el valor intangible de la empresa. Barcelona: Paídos Ibérica, SA.

Sierra-García, L., García-Benau, M.A. and Zorio A., 2014. Credibilidad en latinoamérica del informe de responsabilidad social corporativa. Revista de Administração de Empresas, 54 (1), 28-38.

Sierra-Garcia, L.; Zorio-Grima, A. and García-Benau, M. A., 2013. Sustainable development and assurance of corporate social responsibility reports published by Ibex-35 companies. Corporate Social Responsibility and Environmental Management, 20(6), 359-370. 
Simnett, R., Vanstraelen, A. and Chua, W. F., 2009. Assurance on sustainability reports: an international comparison. The Accounting Review, 84 (3), 937- 967.

Sonnier, B.M., 2008. Intellectual capital disclosure: high-tech versus traditional sector companies. Journal of Intellectual Capital, 9(4), 705-722.

Spangenberg, J. H., 2016. The Corporate Human Development Index CHDI: a tool for corporate social sustainability management and reporting. Journal of Cleaner Production, 134-Part A(15), 414-424.

Steenkamp, N., 2007. Including pictures in intellectual capital reporting research: Does it matter? Paper presented at the Workshop on Visualising, Measuring, and Managing Intangibles \& Intellectual Capital, Ferrara, Italy, 29 - 31 October 2007.

Surroca, J., Tribó, J. A. and Waddock, S., 2010. Corporate responsibility and financial performance: The role of intangible resources. Strategic Management Journal, 31, $463-490$.

Sveiby, K. E., 1997. The New Organizational Wealth: Managing \& Measuring Knowledge-based Assets. San Francisco, Berrett-Koehler Publishers.

Tauringana, V. and Chithambo, L. 2015. The effect of DEFRA guidance on greenhouse gas disclosure. The British Accounting Review, 47(4), 425-444.

Tejedo Romero, F., 2014a. Información del conocimiento organizacional a través de los informes anuales publicados en las páginas web de las empresas. Revista española de Documentación Científica, 37(1).

Tejedo Romero, F., 2014b. Información divulgada del Capital Intelectual en el marco de la Responsabilidad Social Empresarial y del Gobierno Corporativo: evolución y factores determinantes. ICAC, Ministerio de Economía y Competitividad. Madrid

Tejedo Romero, F. and Araujo, J. F. F. E., 2016. Información del Capital Humano: la generación de intangibles y la responsabilidad social. Cuadernos de Gestión, 16(1), 125-144.

Vandemaele, S.N., Vergauwen, P.G.M.C. and Smits, A.J., 2005. Intellectual capital disclosure in The Netherlands, Sweden and the UK: A longitudinal and comparative study. Journal of Intellectual Capital, 6(3), 417-426.

Veltri, S. and Nardo, M.T., 2013. The Intangible Global Report: an integrated corporate communication framework. Corporate Communications: An International Journal, 18 (1), 26-51.

Vuontisjärvi, T., 2006. Corporate social reporting in the European context and human resource disclosures: An analysis of finnish companies. Journal of Business Ethics, 69 (4), 331-354.

White, G., Lee, A. and Tower, G., 2007. Drivers of voluntary intellectual capital disclosure in listed biotechnology companies. Journal of intellectual capital, 8(3), 517-537.

Wooldridge, J. M., 2010. Econometric analysis of cross section and panel data. Massachusetts Institute of Technology Press. Second Edition

Xie, B., Davidson, W. and Dadalt, P., 2003. Earning management and corporate governance: The role of the board and the audit committee. Journal of Corporate Finance, 9, 295-315. 